\title{
Heavy Metal Accumulation is Associated with Molecular and Pathological Perturbations in Liver of Variola louti from the Jeddah Coast of Red Sea
}

\author{
Saleh A. Mohamed 1,*, Mohamed F. Elshal ${ }^{1}$, Taha A. Kumosani ${ }^{1}$, Ahmad O. Mal ${ }^{2}$, \\ Youssri M. Ahmed ${ }^{1}$, Yaaser Q. Almulaiky ${ }^{1}$, Amer H. Asseri ${ }^{1}$ and Mazin A. Zamzami ${ }^{1}$ \\ 1 Biochemistry Department, Faculty of Science; Production of Bioproducts for Industrial Applications Research \\ Group and Experimental Biochemistry Unit, King Fahd Medical Research Center King Abdulaziz University, \\ Jeddah 21589, Saudi Arabia; melshal2002@yahoo.com (M.F.E.); t.kumosani@yahoo.com (T.A.K.); \\ youssri01@yahoo.com (Y.M.A.); yaser_almoliki@yahoo.com (Y.Q.A.); ahasseri@kau.edu.sa (A.H.A.); \\ mzamzami@kau.edu.sa (M.A.Z.) \\ 2 Marine Biology Department, Faculty of Marine Sciences, King Abdulaziz University, Jeddah 21589, \\ Saudi Arabia; aomal@kau.edu.sa \\ * Correspondence: saleh38@hotmail.com; Tel.: +966-543-395-119; Fax: +966-126-952-288 \\ Academic Editor: William A. Toscano \\ Received: 27 January 2016; Accepted: 11 March 2016; Published: 21 March 2016
}

\begin{abstract}
Large amounts of waste water are discharged daily from the Jeddah Metropolitan Area into the Red Sea. Sewage draining into the Red Sea causes widespread chemical pollution that is toxic to aquatic ecosystems. The objective of this study was to investigate the extent of pollution and assess the presence of heavy metals in fish tissue and study their association with biological and biochemical alterations. The average concentrations of heavy metals found in hepatic tissues of Variola louti fish from the polluted area, namely $\mathrm{Cd}, \mathrm{Cr}, \mathrm{Cu}, \mathrm{Fe}$ and $\mathrm{Zn}$, were 1.74, 9.69, 47.48, 4020.01 and $229.47 \mu \mathrm{g} / \mathrm{g}$ liver, respectively, that were significantly higher than that of samples taken from reference area $(0.24$, $1.98,20.12,721.93,129.21 \mu \mathrm{g} / \mathrm{g}$ liver, respectively). The fold change of heavy metals in fish from the polluted area with respect of that of the reference area followed the order $\mathrm{Cd}>\mathrm{Fe}>\mathrm{Cr}>\mathrm{Cu}>\mathrm{Zn}$. Analysis of nuclear DNA revealed that hepatic tissues of fish samples from the polluted area showed a significant increase in apoptotic cells as detected by flow cytometry and formation DNA-ladder. In addition, hepatic sections from polluted area fishes showed more fibrotic changes and collagen deposition by hematoxylin-eosin staining and Masson's trichrome staining, respectively, compared to samples taken from the reference area. Moreover, the electrophoretic patterns of proteins of liver of fishes caught at the polluted area showed different patterns of proteins from that of the reference with bands at 42, 130 and $140 \mathrm{kDa}$, which is in a good agreement with the molecular weight of collagen type III. In conclusion, there were significant changes in the tissues of fishes in the polluted area at the cellular and the molecular levels that may be associated with an accumulation of heavy metals. Assessment of fishes as a sensitive biomonitor for the pollution of surface waters that may affect general health of human and wild life is conceivable.
\end{abstract}

Keywords: aquatic pollution; heavy metals; apoptosis; DNA damage; fibrosis; cytotoxicity

\section{Introduction}

A daily load of 100,000 $\mathrm{m}^{3}$ per day of sewage sludge are discharged in the Jeddah Metropolitan Area of the Red Sea which significantly reduces water quality, raises the ecological risk to human health [1], and increases generalized mortality of aquatic life [2]. Pollutants from oil spillages may be directly responsible for deaths of large numbers of aquatic animals, whereas sewage sludge pollutants contains organic material, e.g., faecal debris, which cause decreases in water quality, oxygen depletion 
and changes in $\mathrm{pH}$ values leading to an increase in microbial populations and greater susceptibility of aquatic organisms to attack by pathogens [3-5]. In addition to organic contaminants, heavy metals are considered one of the main groups of pollutants that enter aquatic systems via anthropogenic activities and/or atmospheric deposition. Large amounts of heavy metals contaminating aquatic systems are accumulated and biomagnified through water, sediment, and the aquatic food chain, resulting in devastating impact on the ecological balance of the recipient environment and on a variety of aquatic organisms [6,7]. Excess amounts of these metals entering the aquatic ecosystem may pollute the environment and also affect the food chain and ultimately pose serious human health risks [8].

Ionic forms of metals are generally more toxic due to their ability to react with other ions catalysing the formation of toxic compounds such as oxyradicals. Oxyradicals, which are formed as a result of electron transfer reactions, are of considerable importance in both animals and plants. Some oxyradicals, such as superoxide anion $\left(\mathrm{O}_{2}{ }^{-}\right)$and the hydroxyl radical $\left(\mathrm{OH}^{-}\right)$, can cause serious cellular damage $[9,10]$. Research has indicated that heavy metals may directly affect cellular organelles and components such as nucleic and mitochondrial DNA, and may inhibit some enzymes involved in DNA damage repair causing DNA damage and conformational changes that may lead to cell cycle modulation, and apoptosis [11].

Metals are natural elements of the environment that are found in varying levels in ground and surface waters, and are classified into two types; essential and non-essential elements. Essential elements such as copper $(\mathrm{Cu})$, iron $(\mathrm{Fe})$, manganese $(\mathrm{Mn})$, nickel $(\mathrm{Ni})$ and zinc $(\mathrm{Zn})$ are required for various biochemical and physiological functions, while other metals including cadmium $(\mathrm{Cd})$, chromium $(\mathrm{Cr})$, mercury $(\mathrm{Hg})$, lead $(\mathrm{Pb})$, arsenic $(\mathrm{As})$, and antimony $(\mathrm{Sb})$ are non-essential and play no significant biological role. Living organisms require trace amounts of essential heavy metals, but these can become toxic at high doses [12,13], whereas, non-essential metals such as cadmium [14], chromium [15], copper [16], iron [17] and zinc [18] are highly toxic and can exert their toxicity at low doses, and consequently these five elements rank among the priority metals that are of great public health significance. These metals may accumulate in the food chain and pose carcinogenic and other adverse risks to human health due to bioaccumulation over time. Research has indicated that environmental exposure to heavy metals increases the risk for developing cancers, diabetes, kidney failure and damage to the nervous system $[8,19,20]$. However, connections must be established between the external levels of exposure of these elements, internal levels of tissue contamination and their adverse effects.

As fish are constantly to exposed pollutants in contaminated water, they could be used as excellent biological markers of heavy metals in aquatic ecosystem [21]. In addition, the liver can be regarded as the body's detoxification organ and hence a target organ of various xenobiotic substances. Therefore, we aimed to investigate the levels of heavy metals which contaminate aquatic ecosystems, and identify their adverse effects in liver tissues, DNA damage and new stress proteins of Variola louti as sentinel species in polluted sites of the Jeddah coastal sea water and comparison to fishes from a pristine reference site.

\section{Materials and Methods}

\subsection{Sample Collection and Handling}

Fish samples of the type Variola louti were collected during four different times per year in 2014 and 2015 from two areas of Jeddah's southern Red Sea shore: (i) a polluted area at Al-Badhae, where abundant of sewage was received; (ii) a reference area at Shuarrah. The annual temperature of the sea water in Jeddah city ranged from 25 to $29^{\circ} \mathrm{C}$. Only fish over $20 \mathrm{~cm}$ in length were sampled. Within $2 \mathrm{~h}$ the catch were transferred to 50-L tanks filled with aerated seawater and transported to the laboratory where the individuals were dissected during the same day. The dissected liver tissues were frozen and stored at $-80^{\circ} \mathrm{C}$ until biomarker analyses. The fishing was conducting according to (Decree No. 21911, 7 November 1988) of Ministry of Agriculture, Kingdom of Saudi Arabia. Fish sampling was authorized 
by Royal Coast Guard of Kingdom of Saudi Arabia (Decree No. 2, 3 February 1990). King Abdulaziz University abides by Royal Decree No. M/59, 24 August 2010 entitled “Research Ethics for Handling of Living Animals".

\subsection{Preparation of Tissue Homogenates}

A 200-300 mg slice of liver was homogenized in cold homogenizing buffer (100 mM $\mathrm{K}_{2} \mathrm{HPO}_{4} / \mathrm{KH}_{2} \mathrm{PO}_{4}, 150 \mathrm{mM} \mathrm{KCl}, 1 \mathrm{mM}$ dithiothreitol, $1 \mathrm{mM}$ EDTA, $\mathrm{pH}$ 7.5) at a ratio of 1:5 (weight:volume). The homogenates were centrifuged at $12,000 \mathrm{~g}$ for $20 \mathrm{~min}$ at $4{ }^{\circ} \mathrm{C}$. The supernatant were collected and stored at $-80^{\circ} \mathrm{C}$ until use.

\subsection{Trace Metals Determination}

Trace metals determination was performed as previously described by Santos et al. [6] with minor modifications. Briefly, each one g of liver tissue sample was heated in a porcelain crucible at $600{ }^{\circ} \mathrm{C}$ for $16 \mathrm{~h}$. Ten $\mathrm{mL}$ of deionized water was added and filtered through Whatman No. 1 filter paper. The filtrate was analyzed for levels of $\mathrm{Cd}, \mathrm{Cu}, \mathrm{Cr}$, Fe and $\mathrm{Zn}$ by inductively coupled plasma atomic emission spectrometry (ICPE-9000; Shimadzu Scientific Instruments Inc., Kyoto, Japan).

\subsection{DNA Flow Cytometry Analysis}

DNA-cell cycle distribution was investigated by flow cytometry after staining the cells with propidium iodide (PI). Small pieces of the liver were minced and disaggregated mechanically using nylon mesh into cell suspension. Cells were washed with phosphate-buffer saline (PBS) and centrifuged at $100 \mathrm{~g}$ for $5 \mathrm{~min}$, the cell pellet was suspended with $70 \%$ ethanol and kept at $-20{ }^{\circ} \mathrm{C}$ for $12 \mathrm{~h}$. Then, the cells were washed with cold PBS and suspended in PBS containing $20 \mu \mathrm{g} / \mathrm{mL}$ PI, $0.2 \mathrm{mg} / \mathrm{mL}$ RNase A and $0.1 \%$ Triton $\mathrm{X}-100$ at $4{ }^{\circ} \mathrm{C}$ for $12 \mathrm{~h}$. The stained cells were then analyzed by a FACSCalibur System flow cytometer (Becton Dickinson Biosciences, San Jose, CA, USA). To analyze apoptosis, hypodiploid DNA (Sub-G1) populations were assayed using a FACSCalibur flow cytometer with Cell Quest software (Becton Dickinson) as previously described [22]. For all assays, 10,000 events were counted and the percentage of apoptotic cells was determined using ModFit software.

\subsection{DNA-Ladder Fragmentation Assay}

The Apoptotic-LADDER assay requires the preparation of nucleosomal DNA to investigate the presence of DNA fragmentations. The procedure does not involve the use of toxic phenol. The protocol involves cell lysis; removal of cellular debris and subsequent precipitation of nucleosomal DNA. Nucleosomal DNA is detected after standard 1.8\% agarose gel electrophoresis. Single cell suspension from the liver samples was prepared and cells were pelleted at $2000 \times \mathrm{g}$ for $20 \mathrm{~s}$ and resuspended in $100 \mu \mathrm{L}$ of phosphate-buffered saline. DNA was extracted by the method of Hirt [23], with minor modifications. Briefly, the cell suspension was lysed by adding $400 \mu \mathrm{L}$ of TE buffer $(10 \mathrm{mM}$ Tris- $\mathrm{HCl}$ buffer, pH 7.4 and $10 \mathrm{mM}$ EDTA) containing $0.6 \%$ sodium lauryl sulfate. The cell lysate was gently mixed with $125 \mu \mathrm{L}$ of $5 \mathrm{M} \mathrm{NaCl}$ and kept at $4{ }^{\circ} \mathrm{C}$ for two hours. The mixture was centrifuged at $14,000 \times g$ for $30 \mathrm{~min}$, and the chromatin pellet was then removed. After treatment with RNase and proteinase K, DNA in the supernatant was precipitated with ethyl alcohol and resuspended in TE buffer. Samples were analyzed for a nucleosomal DNA ladder by electrophoresis on a $1.8 \%$ agarose gel. DNA extracts were quantified using NanoDrop ND-1000 (Thermo Fisher Scientific Inc., Wilmington, DE, USA) as previously descriped [24]. Agarose gel electrophoresis was used to detect DNA fragments after DNA extraction. Briefly, $1.8 \%$ agarose gel was prepared and $35 \mu \mathrm{L}$ ethidium bromide was added. The gel was then placed into electrophoresis tank containing sufficient TAE buffer and three $\mu$ L DNA sample mixed with $2 \mu \mathrm{L}$ loading buffer was carefully loaded into wells on the gel. Appropriate molecular weight marker (1 kb ladder marker) (Jena Bioscience, \#M-217, Jena, Germany) was also included in the same gel. The power supply was connected and adjusted to 100 volts for $60 \mathrm{~min}$. 


\subsection{SDS-Polyacrylamide Gel Electrophoresis}

Electrophoresis under denaturing conditions was performed in $10 \%(\mathrm{w} / \mathrm{v})$ acrylamide slab gel according to the method of Laemmli [25] using a Tris-glycine buffer, $\mathrm{pH}$ 8.3. Protein bands were located by staining with Coomassie Brilliant Blue R-250.

\subsection{Light Microscopy}

Hepatic tissues from all fishes were fixed in 10\% neutral buffered formaldehyde solution ( $\mathrm{pH} 7.0$ ). After fixation was complete (minimum time: 18-24 h), the tissues were processed by a routine histological method and stained by hematoxylin and eosin (H\&E) as previously described [26]. Masson's trichrome stain was applied to demonstrate fibrotic tissue. The intensity of Masson's trichrome blue color staining depended on the content of collagen fibers in the investigated tissue [27]. In the Masson trichrome stained sections, the collagen quantitative analysis in liver was performed in three non-serial sections per fish, totaling 15 sections per group. The sections were analyzed using a BX51 microscope (Olympus, Melville, NY, USA) equipped with filters to provide circularly polarized illumination. All image acquisition parameters and the intensity of acquisition illumination were standardized by adjusting only the microscope condenser aperture. The images were obtained with an $\times 40$ objective lens, recorded on a digital camera (DP-71, Olympus, Melville, NY, USA) and analyzed using Image $\mathrm{J}^{\circledR}$ image analysis software (http:/ /rsbweb.nih.gov/ij/webcite). The analysis methodology was adapted from a method on the NIH website used to quantify stained liver tissue using a thresholding algorithm (http://rsbweb.nih.gov/ij/docs/examples/stained-sections/index.html) with minor modification. Briefly, Each image was converted from a RGB color image to a RGB stack (grayscale) and analyzed in the red channel. We noted three areas of interest within the grayscale image: a lighter gray region representative of stained cytosol (pink in color image), a significantly dark gray region representative of the stained collagen (blue in color image), and a white region indicative of dead space within in the liver section. Grayscale image was used, then the red-stained collagen was isolated using thresholding function. After that, the thresholded area was measured and results were reported as the percentage of collagen area per image as previously described [28].

\subsection{Statistical Analysis}

The statistical analyses were performed by a one-way ANOVA using Bonferroni's post hoc test and the Student's $t$-test. Levene's test of homogeneity of variances was used to assess data distribution. The results were expressed as means \pm S.D. Differences were considered significant when $p<0.05$.

\section{Results Discussion}

In the last two decades, the rate of urbanization and industrialization has increased in Saudi Arabia. Besides the many problems associated with such social changes, pollution is considered to be a major concern for the health of the nation. Among the numerous types of environmental pollutions that threaten human health, contamination of surface waters and the surrounding aquatic ecosystem appear to be a growing threat that requires immediate attention and action. Research has indicated that there is a good correlation between the presence of pollutants in fish and the levels in the surrounding aquatic environment. For example, heavy metals in the tissues of chub (Squalius cephalus) and roach (Rutilus rutilus) obtained from the polluted waters around Czech Republic [29], Tilapia sp. and Chrysichthys sp. from the Ogun river of Nigeria [30] and Sava river at Zagreb [31]. In the present study, there was a significant increase $(p<0.001)$ in the content of $\mathrm{Cd}, \mathrm{Cr}, \mathrm{Cu}, \mathrm{Fe}$ and $\mathrm{Zn}$ in the liver of fishes from polluted area in comparison to that from the reference area $(1.74,9.69,47.48,4020.01$ and 229.47 versus $0.24,1.98,20.12,721.93,129.21 \mu \mathrm{g} / \mathrm{g}$ liver, respectively). The fold increase of heavy metals in fish from polluted area with respect of that of reference area followed the order $\mathrm{Cd}>\mathrm{Fe}>\mathrm{Cr}$ $>\mathrm{Cu}>\mathrm{Zn}$ (Figure 1). 


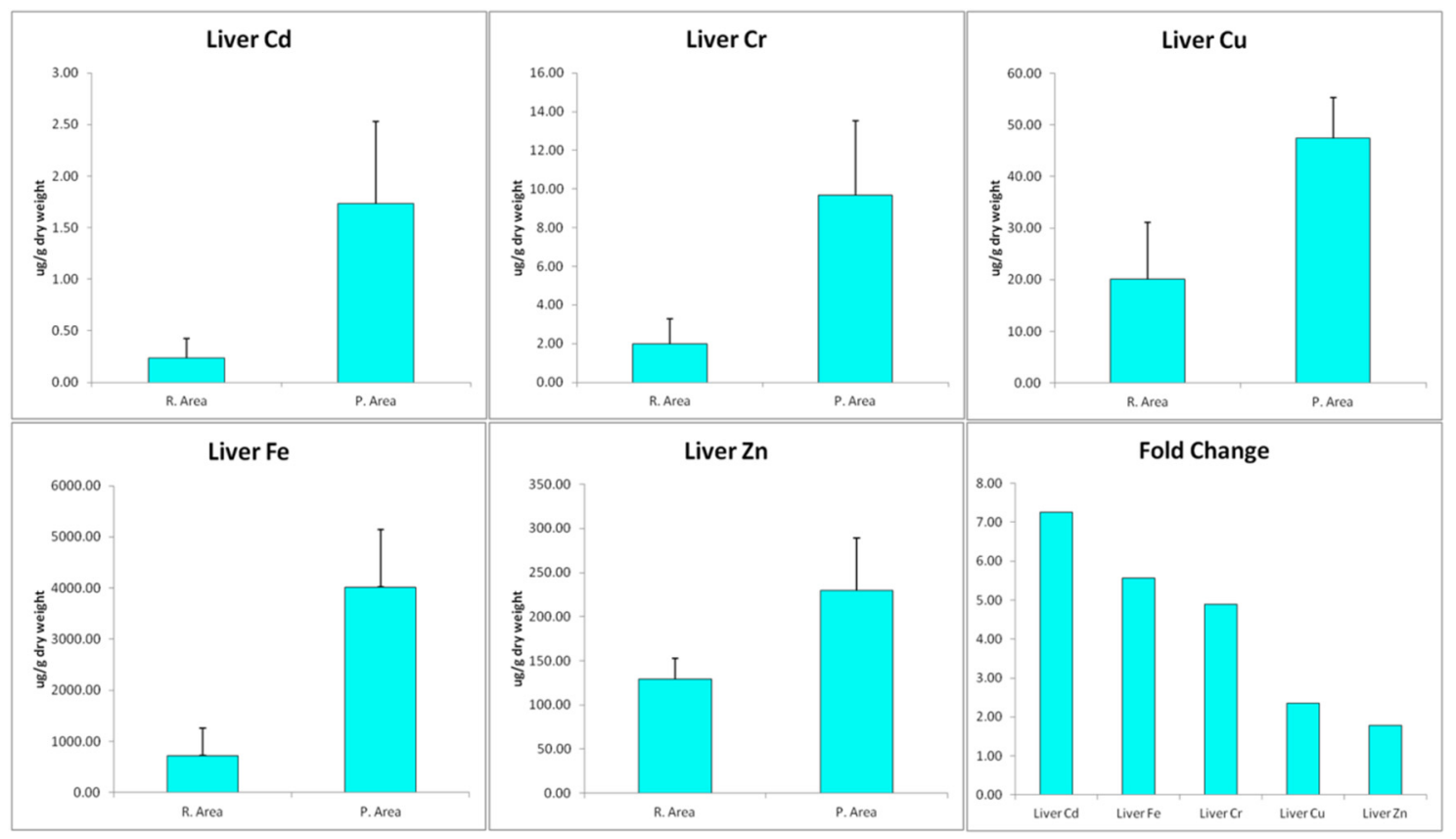

Figure 1. Concentrations of $\mathrm{Cd}, \mathrm{Cr}, \mathrm{Cu}, \mathrm{Fe}$ and $\mathrm{Zn}$ in hepatic tissues $(\mu \mathrm{g} / \mathrm{g})$ of Variola louti.

In the hepatic tissues, $\mathrm{Cd}$ showed the largest fold increase, while $\mathrm{Zn}$ had the lowest fold change in samples from the polluted area in comparison with that from the reference area. Cd may enter the atmosphere from mining, smelting, refining, and manufacturing processes. Excess $\mathrm{Cd}$ can cause serious damage to the brain, kidneys, nervous system and red blood cells. Young children, infants and fetuses are particularly susceptible to $\mathrm{Cd}$ poisoning compared to adults. Recent research has indicated that $\mathrm{Cd}$ may be implicated in causing various types of cancer, including renal [32], breast [33], pancreas [34], endometrial, and ovarian [35] and laryngeal and nasopharyngeal cancer [36]. Cadmium exposure has been associated with increased cancer risk, and low $\mathrm{Zn}$ levels appears to reduce exacerbate $\mathrm{Cd}$ carcinogenicity. Lin, et al. [37] demonstrated that $\mathrm{Cd}$ exposure is an important independent risk factor of cancer mortality in older Americans with low Zn intake. There are multiple molecular mechanism by which $\mathrm{Cd}$ induce cancer and the most important among them are aberrant gene expression, inhibition of DNA damage repair and induction of apoptosis [38,39]. Apoptosis or programmed cell death is a unique form of cell death that is associated with mechanism of morphogenesis and the normal cell turnover of adult tissues. It is recognized by its characteristic cellular morphology, particularly chromatin condensation in the nucleus and plasma membrane blebbing [40]. Later, it was found that apoptotic cells undergo internucleosomal cleavage of DNA forming a "ladder" pattern on agarose gel electrophoresis [41]. These morphological and biochemical features are accepted to be important criteria for confirmation of apoptosis. Previous research indicated that activation of endogenous endonuclease by cadmium result in DNA degradation, morphological and biochemical alterations seen in apoptosis [42]. In agreement with these data, analysis of DNA in our study revealed that hepatic tissues of fish samples from polluted area have significant increase in apoptotic cells as detected by flow cytometry (Figure 2) and formation DNA-ladder (Figure 3) in comparison to samples from reference area. These data suggest that $\mathrm{Cd}$ may play a role in these findings.

The present study also showed that the liver of fish samples from the polluted area contain significantly higher concentrations of $\mathrm{Cr}$ and $\mathrm{Cu}$ in comparison to those from the reference area. The $\mathrm{Cr}$ values detected in this study in both the reference and polluted areas were above the FAO limiting standards of $0.15 \mu \mathrm{g} / \mathrm{g}$ for food fish [43]. 

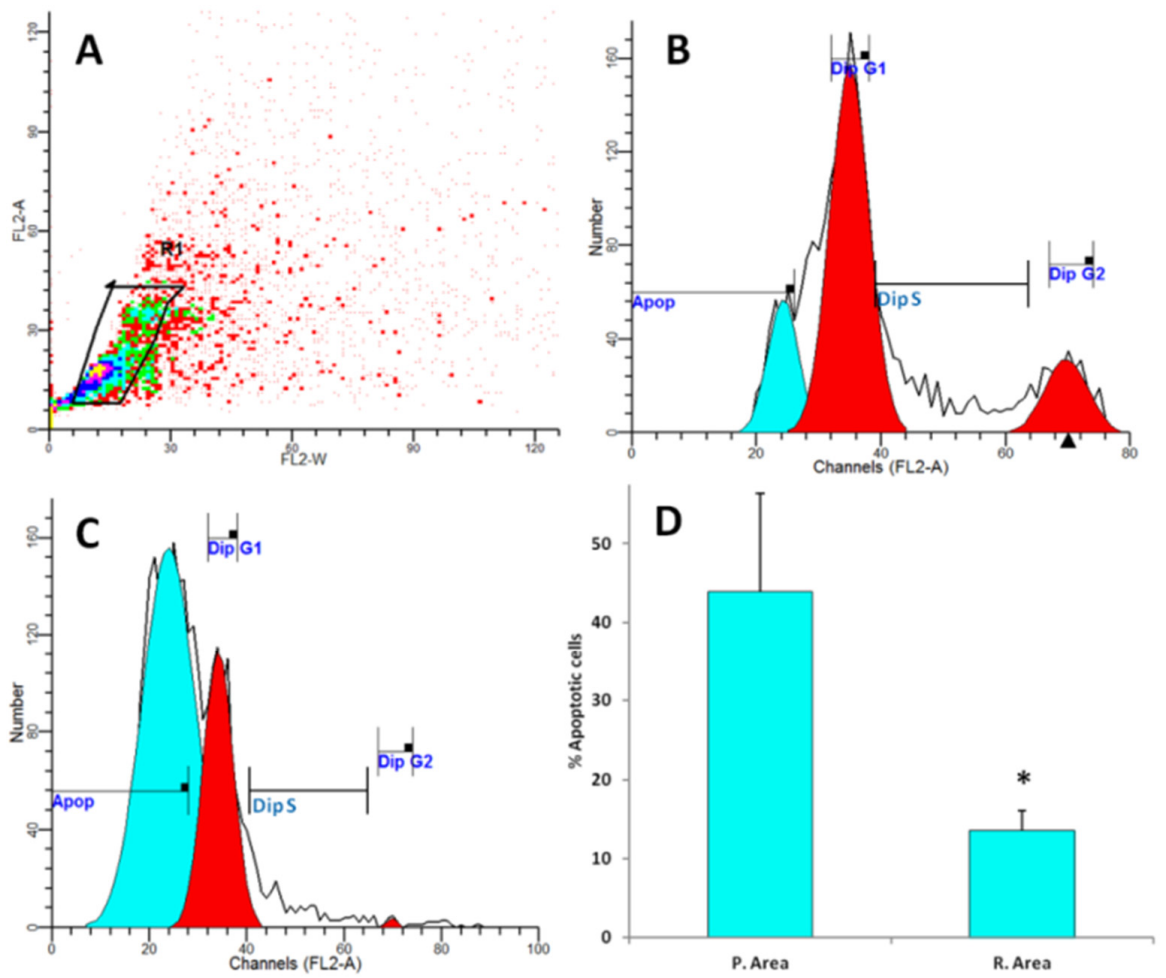

Figure 2. Representative flow cytometry histograms demonstrating the cell cycle phases as determined by propidium iodide staining. (A) gating out doublet events on the basis of FL-2A versus FL-2W; $(B, C)$ cell cycle phases of hepatic tissues from reference and polluted area respectively; (D) the average of apoptotic cells percentage. Values represent the means $\pm \mathrm{SD},{ }^{*} p<0.05$ (Student $t$-test).

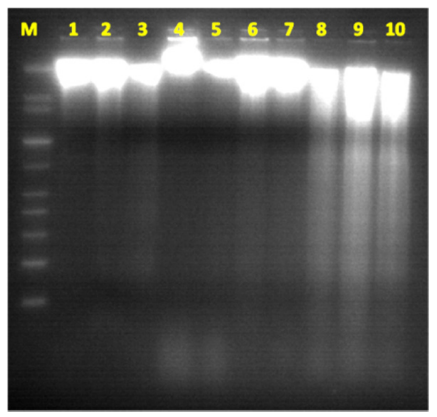

Figure 3. DNA-ladder fragmentation. The genomic DNA extracted from hepatic tissues showed a very weakly stained smear pattern upon electrophoresis, with no evidence of DNA-ladder pattern except from the reference area (1-5). In contrast, the genomic DNA extracted from samples (6-10) of polluted area revealed internucleosomal fragmentation (ladder pattern) mixed with a smear-like pattern, which are classified as signs of apoptosis and necrosis.

The WHO has proposed that $\mathrm{Cr}$ is a human carcinogen. Several studies have shown that chromium (VI) compounds can increase in risk of lung cancer [44,45]. The copper contents in the samples were also higher than the FAO-permitted level in fishes $(3.0 \mu \mathrm{g} / \mathrm{g})$. Excessive intake of copper may lead to liver cirrhosis. Hepatic copper accumulation occurs in a number of cholestatic diseases and they play an important part in pathogenesis and can occasionally lead to neurological toxic effects. Copper overload in the new-born period when biliary excretion of copper is inefficient may establish a vicious cycle of copper accumulation and liver damage [46].

In addition to copper, research indicate that iron deposition causes progressive liver cell damage and is involved the pathogenesis of liver cirrhosis and fibrosis [47]. Interestingly, Fe levels presented the second largest increase in samples from the polluted area. Iron is an essential element involved in 
various biological processes including oxygen transport, electron transport and various enzymatic reactions such as DNA synthesis, transcriptional regulation, catalysis as well as nitric oxide (NO) and oxygen sensing [48]. Several research studies demonstrated that deregulated cellular and systemic iron metabolism would lead to cytotoxicity and increased risk for various diseases, including nephrotoxicity and renal cancer [49,50]. In addition, it was demonstrated that iron induced tissue lipid peroxidation, apoptosis, and formation of 8-hydroxydeoxyguanosine, a known DNA oxidative modification [50].

In mammals, iron overload, especially at sites of storage such as the liver, enhances oxidative stress leading to lipid, nucleic acid and protein peroxidation. In the liver, lipid peroxidation results in damage to hepatocellular organelles, such as mitochondria and lysosomes, which is thought to contribute to hepatocyte necrosis and apoptosis, and ultimately lead to the development of hepatic fibrogenesis [51]. Fibrosis is associated with major quantitative and qualitative changes in the extracellular matrix including increased expression of fibrillary collagens I and III, collagen IV, fibronectin, elastin and laminin [52,53]. To test if the increased content of iron in our samples may associates with liver fibrosis, we examined hepatic sections for fibrotic changes and collagen deposition by hematoxylin-eosin staining and Masson's trichrome staining, respectively. The intensity of Masson's trichrome blue color staining depended on the content of collagen fibers in the investigated tissue [27]. We found that liver sections from polluted area exhibited significant fibrotic alterations and increased percentage of collagen stained area in comparison to samples taken from reference area (Figure 4).

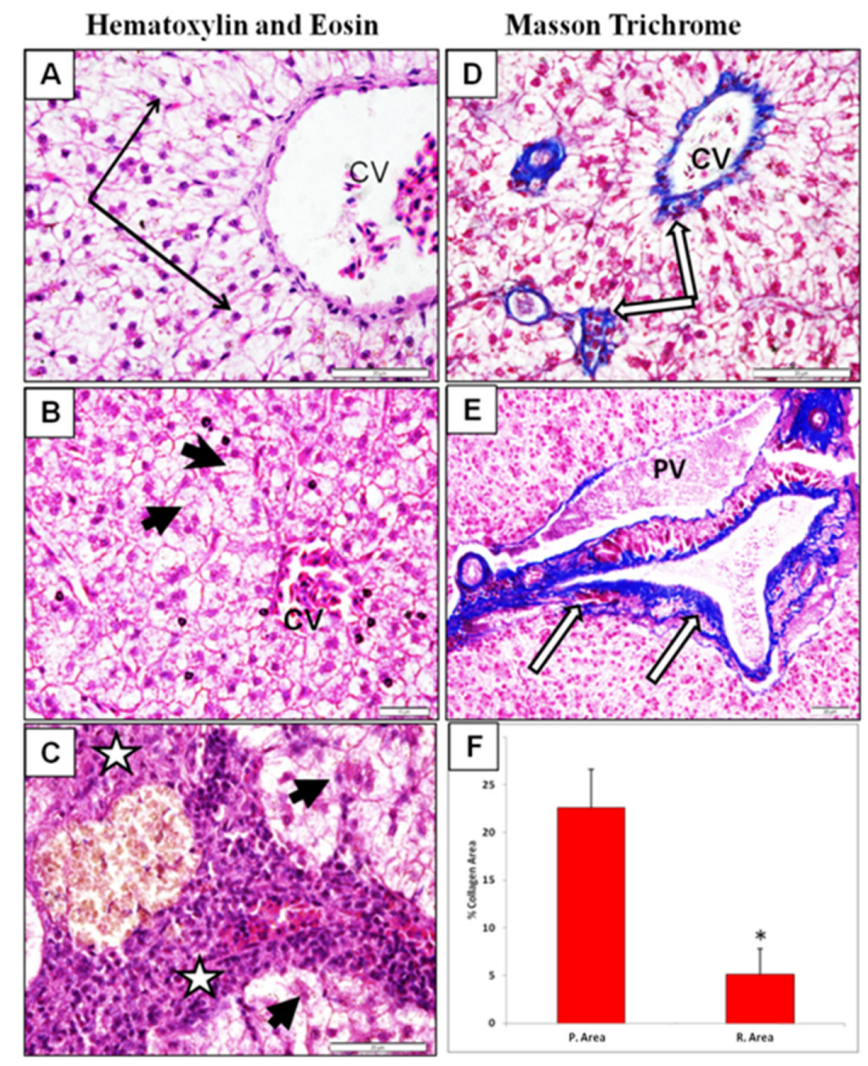

Figure 4. Liver sections stained with $\mathrm{H} \& \mathrm{E}(\mathbf{A}-\mathbf{C})$ and Masson trichrome for collagen (D,E); (A) Sections of fish from reference area exhibiting normal hepatocyte cell cords around the central vein $(\mathrm{CV})$ (black arrows). In polluted group (B,C) there is loss of normal organization and marked fibrosis and inflammatory cell infiltrate (stars) with swollen hepatocytes filled with lipid droplets (arrow head); (D) liver section from reference area stained with Masson trichrome showing moderate increase in collagen fiber deposition around the CV (white arrows); (E) liver sample from polluted area near portal vein region showing marked increase in collagen fiber deposition. Notice the dark staining of hepatocytes in polluted group (white arrow); (F) Quantitative assessment of collagen percentage using ImageJ software as described in methods. Values represent the means $\pm \mathrm{SD},{ }^{*} p<0.05$ (Student $t$-test). 
During liver fibrosis, the liver total collagen content is increased by four- to seven-fold, in particular type I and type III and IV collagens [54]. In the present study, electrophoretic patterns of proteins of liver of Variola louti fish caught in the polluted area showed similar protein patterns as the reference area, except for some protein bands that appeared in polluted area fish (Figure 5). Protein bands of $50 \mathrm{kDa}$ appeared in five samples from the polluted area (lanes 6-10). Unusual protein bands situated at 130 and $140 \mathrm{kDa}$ were also detected in polluted area samples, which is in a good agreement with the molecular weight of collagen type III. In a previous investigation, Mohamed [55] attributed pathological alterations in liver of Oreochromis niloticus and Lates niloticus from Lake Nasser, Egypt to the cumulative effect of metals and the increase in their concentrations in the liver.

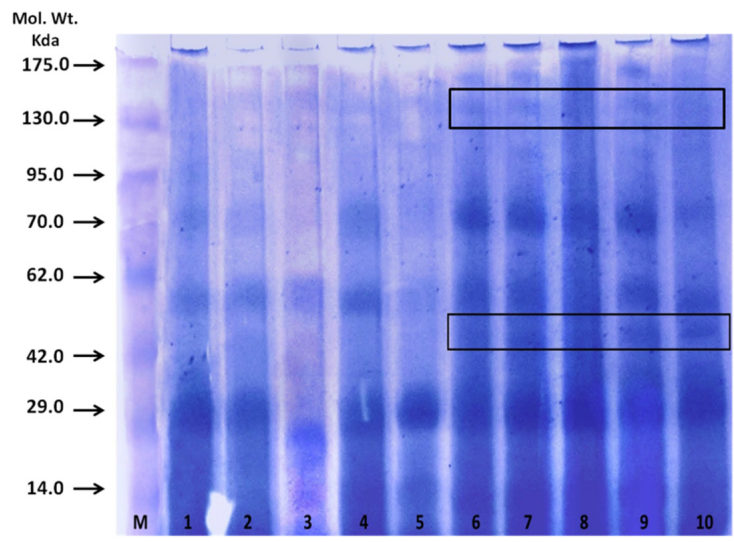

Figure 5. The electrophoretic patterns of proteins of liver of Variola louti fish caught in the reference (1-5) and polluted areas (6-10).

\section{Conclusions}

In conclusion, heavy metals in polluted water have an impact on the DNA and protein of fishes taken from this polluted water. Thus, ingestion of contaminated seafoods should receive special attention in order to protect human beings from these dangerous hazards. Assessment of fishes may provide a tool to monitor risks to general health of human and wild life.

Acknowledgments: This project was funded by the National Plan for Science, Technology and Innovation (MAARIFAH)-King Abdulaziz City for Science and Technology-the Kingdom of Saudi Arabia-award number (12-ENV2243-03). The authors also, acknowledge with thanks Science and Technology Unit, King Abdulaziz University for technical support. Special thanks to Soad Shaker Ali, Associated Professor of Histology. Faculty of Medicine. King Abdulaziz University for her assistant in histology.

Author Contributions: Saleh A. Mohamed, Mohamed F. Elshal had the original idea for the study and carried out the design, Saleh A. Mohamed, Mohamed F. Elshal, Taha A. Kumosani, Ahmad O. Mal were responsible for recruitment and follow-up of study participants. Saleh A. Mohamed, Mohamed F. Elshal, Yaaser Q. Almulaiky carried out the analyses. Youssri M. Ahmed, Amer H. Asseri, Mazin A. Zamzami were responsible for data cleaning and Saleh A. Mohamed, Mohamed F. Elshal, drafted the manuscript, which was revised by all authors. All authors read and approved the final manuscript.

Conflicts of Interest: The authors declare no conflict of interest.

\section{Abbreviations}

The following abbreviations are used in this manuscript:

$\begin{array}{ll}\text { R. Area } & \text { Reference area } \\ \text { P. Area } & \text { Polluted area } \\ \text { CV } & \text { central vein } \\ \text { OD } & \text { optic density } \\ \text { FL-A } & \text { peaks area } \\ \text { FL-W } & \text { peaks width } \\ \text { FCM } & \text { flow cytometry }\end{array}$




\section{References}

1. Pena-Garcia, D.; Ladwig, N.; Turki, A.J.; Mudarris, M.S. Input and dispersion of nutrients from the Jeddah Metropolitan area, Red Sea. Mar. Pollut. Bull. 2014, 80, 41-51. [CrossRef] [PubMed]

2. Doust, J.L.; Schmidt, M.; Doust, L.L. Biological assessment of aquatic pollution: A review, with emphasis on plants as biomonitors. Biol. Rev. Camb. Philos. Soc. 1994, 69, 147-186. [CrossRef] [PubMed]

3. Araujo, R.M.; Arribas, R.M.; Pares, R. Distribution of aeromonas species in waters with different levels of pollution. J. Appl. Bacteriol. 1991, 71, 182-186. [CrossRef] [PubMed]

4. Yoon, H.S.; Aslam, Z.; Song, G.C.; Kim, S.W.; Jeon, C.O.; Chon, T.S.; Chung, Y.R. Flavobacterium sasangense sp. Nov., isolated from a wastewater stream polluted with heavy metals. Int. J. Syst. Evolut. Microbiol. 2009, 59, 1162-1166. [CrossRef] [PubMed]

5. Panero, C.; Grasso, A.; La Cauza, C.; Ragazzini, F.; Bosco, G. Drinking water pollution and Pseudomonas aeruginosa infections in a department for premature infants. G Batteriol. Virol. Immunol. 1970, 63, 517-527. [PubMed]

6. Santos, I.; Diniz, M.S.; Carvalho, M.L.; Santos, J.P. Assessment of essential elements and heavy metals content on Mytilus galloprovincialis from river Tagus estuary. Biol. Trace Element Res. 2014, 159, 233-240. [CrossRef] [PubMed]

7. Saeedi Saravi, S.S.; Shokrzadeh, M. Heavy metals contamination in water and three species of most consumed fish sampled from Caspian sea, 2011. Environ. Monit. Assess. 2013, 185, 10333-10337. [CrossRef] [PubMed]

8. Zhao, Q.; Wang, Y.; Cao, Y.; Chen, A.; Ren, M.; Ge, Y.; Yu, Z.; Wan, S.; Hu, A.; Bo, Q.; et al. Potential health risks of heavy metals in cultivated topsoil and grain, including correlations with human primary liver, lung and gastric cancer, in Anhui province, Eastern China. Sci. Total Environ. 2014, 470-471, 340-347. [CrossRef] [PubMed]

9. Chesman, B.S.; O'Hara, S.; Burt, G.R.; Langston, W.J. Hepatic metallothionein and total oxyradical scavenging capacity in atlantic cod Gadus morhua caged in open sea contamination gradients. Aquat. Toxicol. 2007, 84, 310-320. [CrossRef] [PubMed]

10. Canesi, L.; Ciacci, C.; Piccoli, G.; Stocchi, V.; Viarengo, A.; Gallo, G. In vitro and in vivo effects of heavy metals on mussel digestive gland hexokinase activity: The role of glutathione. Comp. Biochem. Physiol. Part C Pharmacol. Toxicol. Endocrinol. 1998, 120, 261-268. [CrossRef]

11. Wang, S.; Shi, X. Molecular mechanisms of metal toxicity and carcinogenesis. Mol. Cell. Biochem. 2001, 222, 3-9. [CrossRef] [PubMed]

12. Frieden, E. The evolution of metals as essential elements (with special reference to iron and copper). Adv. Exp. Med. Biol. 1974, 48, 1-29. [PubMed]

13. Tchounwou, P.B.; Yedjou, C.G.; Patlolla, A.K.; Sutton, D.J. Heavy metal toxicity and the environment. In Molecular, Clinical and Environmental Toxicology; Springer: Berlin, Germany, 2012; pp. 133-164.

14. Badisa, V.L.; Latinwo, L.M.; Odewumi, C.O.; Ikediobi, C.O.; Badisa, R.B.; Brooks-Walter, A.; Lambert, A.T.; Nwoga, J. Cytotoxicity and stress gene microarray analysis in cadmium-exposed crl-1439 normal rat liver cells. Int. J. Mol. Med. 2008, 22, 213-219. [PubMed]

15. Flores, A.; Perez, J.M. Cytotoxicity, apoptosis, and in vitro DNA damage induced by potassium chromate. Toxicol. Appl. Pharmacol. 1999, 161, 75-81. [CrossRef] [PubMed]

16. Gabbianelli, R.; Lupidi, G.; Villarini, M.; Falcioni, G. DNA damage induced by copper on erythrocytes of gilthead sea bream sparus aurata and mollusk scapharca inaequivalvis. Arch. Environ. Contam. Toxicol. 2003, 45, 350-356. [CrossRef] [PubMed]

17. Park, E.; Glei, M.; Knobel, Y.; Pool-Zobel, B.L. Blood mononucleocytes are sensitive to the DNA damaging effects of iron overload-in vitro and ex vivo results with human and rat cells. Mutat. Res. 2007, 619, 59-67. [CrossRef] [PubMed]

18. Roney, N.; Osier, M.; Paikoff, S.J.; Smith, C.V.; Williams, M.; De Rosa, C.T. ATSDR evaluation of the health effects of zinc and relevance to public health. Toxicol. Ind. Health 2006, 22, 423-493. [CrossRef] [PubMed]

19. Baatrup, E. Structural and functional effects of heavy metals on the nervous system, including sense organs of fish. Comp. Biochem. Physiol. C Comp. Pharmacol. Toxicol. 1991, 100, 253-257. [CrossRef]

20. Khan, M.A.; Castro-Guerrero, N.; Mendoza-Cozatl, D.G. Moving toward a precise nutrition: Preferential loading of seeds with essential nutrients over non-essential toxic elements. Front. Plant Sci. 2014, 5, 51. [CrossRef] [PubMed] 
21. Mance, G. Pollution Threat of Heavy Metals in Aquatic Environments; Springer: Berlin, Germany, 1987.

22. Qian, L.; Murakami, T.; Kimura, Y.; Takahashi, M.; Okita, K. Saikosaponin a-induced cell death of a human hepatoma cell line (Huh-7): The significance of the "sub-g1 peak" in a DNA histogram. Pathol. Int. 1995, 45, 207-214. [CrossRef] [PubMed]

23. Hirt, B. Selective extraction of polyoma DNA from infected mouse cell cultures. J. Mol. Biol. 1967, 26, 365-369. [CrossRef]

24. Boesenberg-Smith, K.A.; Pessarakli, M.M.; Wolk, D.M. Assessment of DNA yield and purity: An overlooked detail of PCR troubleshooting. Clin. Microbiol. Newslett. 2012, 34, 1-6. [CrossRef]

25. Laemmli, U. Most commonly used discontinuous buffer system for SDS electrophoresis. Nature 1970, 227, 680-685. [CrossRef] [PubMed]

26. Delafield, F. Haematoxylin and eosin for general staining. In Staining of the Animal Tissues Practical and Theoretical; Oxford University Press: London, UK, 1984.

27. Yokoo, T.; Wolfson, T.; Iwaisako, K.; Peterson, M.R.; Mani, H.; Goodman, Z.; Changchien, C.; Middleton, M.S.; Gamst, A.C.; Mazhar, S.M.; et al. Evaluation of liver fibrosis using texture analysis on combined-contrast-enhanced magnetic resonance images at 3.0T. BioMed Res. Int. 2015, 2015, 387653. [CrossRef] [PubMed]

28. Whittaker, P.; Kloner, R.A.; Boughner, D.R.; Pickering, J.G. Quantitative assessment of myocardial collagen with picrosirius red staining and circularly polarized light. Basic Res. Cardiol. 1994, 89, 397-410. [CrossRef] [PubMed]

29. Dvorak, P.; Andreji, J.; Dvorakova-Liskova, Z.; Vejsada, P. Assessment of selected heavy metals pollution in water, sediments and fish in the basin Dyje, Czech republic. Neuro Endocrinol. Lett. 2014, 35, 26-34. [PubMed]

30. Adeniyi, A.A.; Yusuf, K.A.; Okedeyi, O.O. Assessment of the exposure of two fish species to metals pollution in the Ogun river catchments, Ketu, Lagos, Nigeria. Environ. Monit. Assess. 2008, 137, 451-458. [CrossRef] [PubMed]

31. Bosnir, J.; Puntaric, D.; Skes, I.; Klaric, M.; Simic, S.; Zoric, I.; Galic, R. Toxic metals in freshwater fish from the Zagreb area as indicators of environmental pollution. Coll. Antropol. 2003, 27, 31-39. [PubMed]

32. Song, J.K.; Luo, H.; Yin, X.H.; Huang, G.L.; Luo, S.Y.; Lin du, R.; Yuan, D.B.; Zhang, W.; Zhu, J.G. Association between cadmium exposure and renal cancer risk: A meta-analysis of observational studies. Sci. Rep. 2015, 5, 17976. [CrossRef] [PubMed]

33. Peng, L.; Huang, Y.; Zhang, J.; Peng, Y.; Lin, X.; Wu, K.; Huo, X. Cadmium exposure and the risk of breast cancer in Chaoshan population of southeast China. Environ. Sci. Pollut. Res. Int. 2015, 22, 19870-19878. [CrossRef] [PubMed]

34. Chen, C.; Xun, P.; Nishijo, M.; Sekikawa, A.; He, K. Cadmium exposure and risk of pancreatic cancer: A meta-analysis of prospective cohort studies and case-control studies among individuals without occupational exposure history. Environ. Sci. Pollut. Res. Int. 2015, 22, 17465-17474. [CrossRef] [PubMed]

35. Adams, S.V.; Quraishi, S.M.; Shafer, M.M.; Passarelli, M.N.; Freney, E.P.; Chlebowski, R.T.; Luo, J.; Meliker, J.R.; $\mathrm{Mu}$, L.; Neuhouser, M.L.; et al. Dietary cadmium exposure and risk of breast, endometrial, and ovarian cancer in the women's health initiative. Environ. Health Perspect. 2014, 122, 594-600. [CrossRef] [PubMed]

36. Eriksen, K.T.; Halkjaer, J.; Sorensen, M.; Meliker, J.R.; McElroy, J.A.; Tjonneland, A.; Raaschou-Nielsen, O. Dietary cadmium intake and risk of breast, endometrial and ovarian cancer in danish postmenopausal women: A prospective cohort study. PLoS ONE 2014, 9, e100815. [CrossRef] [PubMed]

37. Lin, Y.S.; Caffrey, J.L.; Lin, J.W.; Bayliss, D.; Faramawi, M.F.; Bateson, T.F.; Sonawane, B. Increased risk of cancer mortality associated with cadmium exposures in older Americans with low zinc intake. J. Toxicol. Environ. Health Part A 2013, 76, 1-15. [CrossRef] [PubMed]

38. Hengstler, J.G.; Bolm-Audorff, U.; Faldum, A.; Janssen, K.; Reifenrath, M.; Gotte, W.; Jung, D.; Mayer-Popken, O.; Fuchs, J.; Gebhard, S.; et al. Occupational exposure to heavy metals: DNA damage induction and DNA repair inhibition prove co-exposures to cadmium, cobalt and lead as more dangerous than hitherto expected. Carcinogenesis 2003, 24, 63-73. [CrossRef] [PubMed]

39. Bertin, G.; Averbeck, D. Cadmium: Cellular effects, modifications of biomolecules, modulation of DNA repair and genotoxic consequences (A review). Biochimie 2006, 88, 1549-1559. [CrossRef] [PubMed]

40. Kerr, J.F.; Wyllie, A.H.; Currie, A.R. Apoptosis: A basic biological phenomenon with wide-ranging implications in tissue kinetics. Br. J. Cancer 1972, 26, 239. [CrossRef] [PubMed] 
41. Arends, M.; Morris, R.; Wyllie, A. Apoptosis. The role of the endonuclease. Am. J. Pathol. 1990, 136, 593. [PubMed]

42. Lohmann, R.D.; Beyersmann, D. Cadmium and zinc mediated changes of the $\mathrm{Ca}\left({ }^{2+}\right)$-dependent endonuclease in apoptosis. Biochem. Biophys. Res. Commun. 1993, 190, 1097-1103. [CrossRef] [PubMed]

43. FAO. Compilation of legal limits for hazardous substances in fish and fishery products. FAO Fish. Circ. 1983, 464, 5-100.

44. Lurie, P.; Wolfe, S.M. Continuing exposure to hexavalent chromium, a known lung carcinogen: An analysis of Osha compliance inspections, 1990-2000. Am. J. Ind. Med. 2002, 42, 378-383. [CrossRef] [PubMed]

45. Mancuso, T.F. Chromium as an industrial carcinogen: Part I. Am. J. Ind. Med. 1997, 31, 129-139. [CrossRef]

46. Prasad, R.; Kaur, G.; Nath, R.; Walia, B.N. Molecular basis of pathophysiology of Indian childhood cirrhosis: Role of nuclear copper accumulation in liver. Mol. Cell. Biochem. 1996, 156, 25-30. [CrossRef] [PubMed]

47. Ishida, M.; Nakagawara, G.; Imamura, Y.; Fukuda, M. Iron and copper deposition in chronic active hepatitis and liver cirrhosis: Pathogenetic role in progressive liver cell damage. Eur. J. Histochem. 1995, 39, 221-236. [PubMed]

48. Papanikolaou, G.; Pantopoulos, K. Iron metabolism and toxicity. Toxicol. Appl. Pharmacol. 2005, 202, $199-211$. [CrossRef] [PubMed]

49. Guo, W.; Zhang, J.; Li, W.; Xu, M.; Liu, S. Disruption of iron homeostasis and resultant health effects upon exposure to various environmental pollutants: A critical review. J. Environ. Sci. 2015, 34, 155-164. [CrossRef] [PubMed]

50. Zhang, D.; Okada, S.; Yu, Y.; Zheng, P.; Yamaguchi, R.; Kasai, H. Vitamin e inhibits apoptosis, DNA modification, and cancer incidence induced by iron-mediated peroxidation in wistar rat kidney. Cancer Res. 1997, 57, 2410-2414. [PubMed]

51. Ramm, G.A.; Ruddell, R.G. Hepatotoxicity of iron overload: Mechanisms of iron-induced hepatic fibrogenesis. Semin. Liver Dis. 2005, 25, 433-449. [CrossRef] [PubMed]

52. Neubauer, K.; Saile, B.; Ramadori, G. Liver fibrosis and altered matrix synthesis. Can. J. Gastroenterol. 2001, 15, 187-193. [PubMed]

53. Biagini, G.; Ballardini, G. Liver fibrosis and extracellular matrix. J. Hepatol. 1989, 8, 115-124. [CrossRef]

54. Attallah, A.M.; Mosa, T.E.; Omran, M.M.; Abo-Zeid, M.M.; El-Dosoky, I.; Shaker, Y.M. Immunodetection of collagen types I, II, III, and IV for differentiation of liver fibrosis stages in patients with chronic HCV. J. Immunoass. Immunochem. 2007, 28, 155-168. [CrossRef] [PubMed]

55. Mohamed, F.A. Bioaccumulation of selected metals and histopathological alterations in tissues of Oreochromis niloticus and lates niloticus from lake Nasser, Egypt. Glob. Vet. 2008, 2, 205-218. 